This is the penultimate draft of an article that has been published in: HOPOS: The Journal of the International Society for the History of Philosophy of Science 10:1 (Spring 2020), 308328. DOI: https://doi.org/10.1086/707912

\title{
From Völkerpsychologie to Cultural Anthropology: \\ Erich Rothacker's Philosophy of Culture
}

Dr. Johannes Steizinger

McMaster University

steizinj@mcmaster.ca ${ }^{1}$

\footnotetext{
${ }^{1}$ This work was supported by the European Research Council (ERC) under Grant 339382. For critical comments and helpful suggestions on earlier drafts of this paper, I want to thank Martin Kusch, Barry Allen, Sandra Lapointe, Martin Strauss, Matthias Schlossberger, Zach Murphy King, and four anonymous referees. I am also grateful to an audience at a workshop in Vienna (April 2018) and my students for discussing the topic of this paper.
} 


\section{Abstract}

Erich Rothacker (1888-1965) was a key figure in early-twentieth-century philosophy in Germany. In this paper, I examine the development of Rothacker's philosophy of culture from 1907 to 1945. Rothacker began his philosophical career with a völkerpsychological dissertation on history, outlining his early biologistic conception of culture (1907-1913). In his mid-career work, he then turned to Wilhelm Dilthey's (1833-1911) Lebensphilosophie (philosophy of life), advancing a hermeneutic approach to culture (1919-1928). In his later work (1929-1945), Rothacker developed a cultural anthropology. I shall argue that Rothacker's later theory of culture retained key motifs of his earlier works. In this way, I trace central aspects of Rothacker's reception of both Völkerpsychologie and Lebensphilosophie. The paper focuses on two aspects of Rothacker's philosophical development that deserve more attention than they have received to date: his reception of Völkerpsychologie and the political character of his theories of culture. Rothacker's theoretical work was closely connected to his political conservatism, which culminated in his engagement with National Socialism. The paper unearths problematic aspects of the legacy of Völkerpsychologie and Lebensphilosophie in early twentieth-century German thought.

\section{Introduction}

Erich Rothacker (1888-1965) was a key figure in early-twentieth-century philosophy in Germany. In this paper, I examine the development of Rothacker's philosophy of culture from 1907 to 1945. Rothacker began his philosophical career with a völkerpsychological dissertation on history, outlining his early biologistic conception of culture (1907-1913). In his mid-career work, he then turned to Wilhelm Dilthey's (1833-1911) Lebensphilosophie (philosophy of life), advancing a hermeneutic approach to culture (1919-1928). In his later 
work (1929-1945), Rothacker developed a cultural anthropology. I shall argue that Rothacker's later theory of culture retained key motifs of his earlier works. In this way, I trace central aspects of Rothacker's reception of both Völkerpsychologie $e^{\mathrm{i}}$ and Lebensphilosophie.

I reconstruct the development of Rothacker's philosophy of culture in three steps: Section 2 outlines Rothacker's völkerpsychological beginnings (1907-1913). This section sketches the intellectual context of his dissertation, analyzes its biologistic concept of culture, and highlights the political implications of this view.

Section 3 explores the middle Rothacker's turn to Lebensphilosophie (1919-1928). The section examines the hermeneutic concept of culture emerging from Rothacker's study of the Diltheyan theory of worldviews. Moreover, here I show the political motivations for Rothacker's theoretical engagement with the legacy of historicism, and show that Rothacker identified with the conservative and nationalist tendencies of the historicist movement.

Finally, section 4 investigates the second fundamental revision of Rothacker's philosophical thought, outlining the methodological and political orientation of his later philosophy (1929-1945). Rothacker associated his new theory of culture with the rise of National Socialism (NS). This section analyzes the key motifs of Rothacker's cultural anthropology, and highlights the connections between this later work and his earlier approaches to culture.

The paper focuses on two aspects of Rothacker's philosophical development that have not received the attention they deserve to date: (a) the significance of his reception of Völkerpsychologie, and (b) the political character of his theories of culture.

\section{a) Rothacker's Reception of Völkerpsychologie}

Most commentators do not focus on Rothacker's völkerpsychological beginnings (Koslowski 1997; Böhnigk 2002; Tremmel 2009, 2012; Plas 2011, 2013; Fischer 2008). Stöwer's (2012a) biography sketches the intellectual context of Rothacker's early work, yet 
does not connect Rothacker's first concept of culture with his later approaches (see also Stöwer 2012b). Stöwer concentrates on the significance of Dilthey's hermeneutics for the development of Rothacker's philosophy of culture. This aspect of his work has been well researched (see Koslowski 1997; Fischer 2008; Plas 2011, 2013; Stöwer 2012a, 2012b; Tremmel 2009, 2012).

The lack of scholarship on Rothacker's völkerpsychological beginnings is all the more surprising when we bear in mind the central themes of Rothacker's life-long work and their close connections with the general orientation of Völkerpsychologie. Rothacker sought to understand the nature of humanity throughout his philosophical career, believing that the special character of humanity was revealed in its historical development, where we see humanity consistently organized in particular groups with distinctive cultural achievements. This common starting point of Rothacker's philosophical projects is similar to the point of view found in Völkerpsychologie. Völkerpsychologie had emerged as a scholarly program in the work of German-Jewish scholars Moritz Lazarus (1824-1903) and Herman Steinthal (1823-1899) (on the development of Völkerpsychologie from 1850 to 1945 see Klautke 2013; Kusch 2019). Lazarus and Steinthal regarded the communal life of social groups as the key to understanding humanity. They emphasized that human communities, especially Völker, developed a common spiritual life (geistiges Leben) and that history was characterized by the development of these spirits of Völker (Volksgeister). Lazarus and Steinthal pursued a scientific approach to what they regarded as the "objective spirit" (objektiver Geist) of communities. They aimed to discover the causal-psychological laws that governed the development of humanity, taking "cultural forms" such as myths, religions, arts, and legal systems as their focus points. The Völkerpsychologie of Lazarus and Steinthal became an important model for understanding humanity through history and culture. This general orientation also guided the approach of Wilhelm Wundt (1832-1920), who was the most important proponent of the second generation of Völkerpsychologie, publishing the ten 
volumes of his Völkerpsychologie between 1900 and 1920. Wundt restricted his approach to the early stages of communal life and defined language, myth, and customs as the central issues of Völkerpsychologie (Wundt 1886/1911). As Lazarus and Steinthal had, Wundt argued that the systematic study of collective psychological processes would yield a developmental history of humanity.

\section{b) The Political Character of Rothacker's Theories of Culture}

It is quite surprising that no in-depth examination of the close connection between Rothacker's theories of culture and his political orientation exists. Fischer (2008), Koslowski (1997), and Habermas (1958/1973) do not delve at all into the political aspect of Rothacker's philosophy. Plas $(2011,2013)$ examines the connection between Rothacker's historicist approaches to culture and his conservative leanings, but argues that the same theory could have lent itself to progressive policies. In my evaluation, here Plas underestimates the völkisch character of Rothacker's philosophy. The same holds for Tremmel's $(2009,2012)$ reading. Tremmel acknowledges that Rothacker's cultural anthropology could open the door for racist theories, but does not analyze the political aspect of its key motifs. Stöwer's (2012a) biography gives a detailed account of Rothacker's political activities during the Weimar Republic and the NS period, yet, by explaining Rothacker's political engagement through psychological motifs, Stöwer does not bring to bear the close connections between this political activity and Rothacker's philosophy. Böhnigk (2002) detects a commitment to biological racism in Rothacker's cultural anthropology, though, as I will show, Rothacker's later work did not center on biology. Weber (1989) only considers Rothacker's public engagement in support for nationalist cultural policies, without analyzing Rothacker's philosophical commitments.

Rothacker is still seen as a key author in philosophical anthropology (Fischer 2008). Several commentators praise his culturalist approach to the historicity of humanity, 
contrasting his emphasis on culture and history with the naturalized concept of 'humanity'. On this reading, naturalistic anthropologies are accused of relying on dogmatic concepts of humanity with problematic political consequences (Habermas 1958/1973; Fischer 2008; Tremmel 2009; Plas 2011). My paper challenges this popular argument. I show that Rothacker justified his political conservativism by biologistic, historicist, and culturalist arguments. Moreover, I argue that his different theories of culture were characterized by a general pattern of völkisch thinking about humanity. It was this pattern that undergirded Rothacker's problematic political views.

\section{The Early Rothacker (1907-1913): Völkerpsychological Beginnings}

A preliminary look at Rothacker's educational background demonstrates that his main philosophical interests emerged in the context of Völkerpsychologie. ${ }^{\mathrm{ii}}$ The early Rothacker engaged intensively with Völkerpsychologie during his studies in Kiel, Strasburg, Munich, and Tübingen. In Kiel, Rothacker studied with Götz Martius (1853-1927), a student of Wundt. During that time, Rothacker (1909) published a review of recent debates around Völkerpsychologie in the renowned Zeitschrift für Angewandte Psychologie (Journal of Applied Psychology). He also began to engage with the social-psychological approach to cultural history in the work of Karl Lamprecht (1856-1915), a close ally of Wundt.

Rothacker's engagement with Lamprecht was the beginning of his dissertation project. In 1912, Rothacker's dissertation was published in the important series Contributions to Cultural and Universal History, edited by Lamprecht himself.

Rothacker's education was profoundly rooted in Völkerpsychologie and in Lamprecht's uses of this tradition. Lamprecht's German History (1891-1909) presented itself as a psychological history of the German nation and prompted the so-called "Lamprecht controversy" (see Schorn-Schütte 1984; Raphael 1990; Chickering 1993; Klautke 2013, 73, 
77 f.). Against the mainstream of contemporary history, Lamprecht's "cultural history" prioritized economic and social history, and focused on collectives rather than individuals. Lamprecht believed that nations were the agents of history, and that they developed in clearly distinguishable psychological stages. He aimed to identify the causal, statistical laws governing this process. Other historians and philosophers of the time accused Lamprecht of "positivism" and "materialism," leaving him with few allies.

It is surprising that, early on, Rothacker chose Lamprecht's genetic historiography as the starting point of his dissertation in philosophy, attempting to defend and improve Lamprecht's conception. In his dissertation, Rothacker held that history was the cultural development of human communities, and that its pattern could be explained biologically, thus agreeing with the general orientation of Lamprecht's "biology of nations." Yet Rothacker felt that Lamprecht had overlooked the physiological foundation of cultural achievements (Rothacker 1912, 118 f.). As Rothacker saw it, Lamprecht's social-psychological approach had to be modified into an examination of the physiological laws that governed the cultural development of human communities. Rothacker claimed that the same laws of organic development governed races, nations, animals, and plants (108). He defined his approach as völkerpsychological (33). In contrast to Wundt, but in line with Lazarus and Steinthal, Rothacker believed that the higher forms of cultural development—-such as science or artcould be explained by völkerpsychological processes (45). Yet he rejected the reference to collective entities such as the Volksseele (soul of the people) as supposed agents of collective development, thus agreeing with the critique of Völkerpsychologie that Georg Simmel (18581918) had put forward in his sociological works $\left(48-50,69\right.$ f.). ${ }^{\text {iii }}$ Rothacker, however, disputed Simmel's (1908) conclusion that cultural forms always resulted from the interaction of individual minds. Rothacker believed in a collective foundation of cultural achievements, disagreeing with Simmel's distinction between the individual-psychological cause and the supraindividual result of the cultural process. The early Rothacker rejected sociological 
explanations in general, skeptical of the suggestion that culture could be caused by the social interactions of individuals. For him, the social organization of a community was only an external framework that could modify cultural development superficially. Rothacker regarded "Völker", "nations," "tribes," "states," and "cities" as the most important social contexts in which cultural developments could manifest in concrete achievements (103-110). These social groups were defined as arbitrary associations of individuals. Rothacker believed that there were social groups without culture. They lacked the natural disposition for developing culture and remained only social organizations (158).

One reason for this belief lies in Rothacker's advancement of a biologistic concept of culture which considers races to be the key agents of human life. Rothacker defined races as natural groups governed by the biological laws of organic growth, and envisaged them as flourishing or degenerating like trees $(95,106 \mathrm{f}$.). He regarded racial dispositions as the ultimate cause behind cultural development. On this account, races generated gifted individuals capable of developing culture, and concrete cultural achievements in turn depended upon individuals with exceptional intellectual capacities (106 f., 125). This explains how Rothacker could claim that his biologistic concept of culture constitutes something of a middle ground between collectivism and individualism (113 f.).

If we follow Rothacker, cultural development was an expression of a community's natural development regarding its intellectual capacities. Rothacker defined these capacities as "formal" (formale Begabung; 79 f.). He compared their development with the organic development of an eye (54), emphasizing that the development of these intellectual capacities was first and foremost an organic process (113). This is not an analogy. Rothacker held that the physiological make-up of human brains was the key source of cultural development. This biologistic rendering of culture was clearly deterministic, and he believed that the intellectual capacities of an individual were completely genetically determined. In this context Rothacker also maintained that the brains of "primitives" were physiologically inferior, claiming that a 
"primitive person's child" raised "among us" would never be capable of belonging to "our highest intellectual class" (80 f., 86 f.): "Nobody can go beyond his innate mind" (88). Of course, the early Rothacker did not think that all members of a community had the same formal capacities, and advocated a quite simple equation: The better your brain, the higher your social position, especially within a cultural domain (see, e.g. $51 \mathrm{f} ., 147-49$ ).

Rothacker believed that he had discovered the natural foundation of cultural differences, and that, from this point of view, he could rank human communities by their formal capacities. He was convinced that these formal capacities could be assessed by the vitality they exhibit (16, $38 \mathrm{f}$.). Thus, for example, he followed Lamprecht in assuming that the history of Germany since the tenth century was characterized by the development of selfconsciousness, and that this change was brought about by an increase of "mental energy" (seelische Energie; 40). He argued that the cultural achievements of communities revealed such changes, since they expressed the organic development of their formal capacities (54 f., 80). Rothacker's theory also shared the universal scope of Lamprecht's and Wundt's approaches to historical development. The early Rothacker envisaged cultural processes as continuous developments always following the same formal stages (53). He claimed that these empirical regularities could be found in all cultures, forming a clear hierarchy of cultural development.

To illustrate his understanding of cultural development, Rothacker contrasted the primitive stage of knowledge with what he regarded as the highest stage. The inferior brain of "primitives," he argued, resulted in the weakness of their formal capacity for knowledge. "Primitives" necessarily perceived the world falsely, expressing a distorted cognition of reality in their mythological worldviews. Rothacker claimed that this form of knowledge was guided by the needs of primitive life, assuming that at the lowest stage, knowledge was entirely relative to practical interests (62-66). However, with the organic development of the brain, the formal capacity of knowing also improved (see, e.g., $101 \mathrm{f}$.). At the "highest" 
cognitive stage, formal capacities enabled humans to gain objective knowledge about the world. At this point, knowledge was pursued for its own sake (53 f., 65 f.). Since the highest form of knowing was independent of external influences, Rothacker regarded it as absolute (109). He argued that the investigations of modern science were characterized by this "purely formal, objective, and critical spirit" (71). Early on, Rothacker extended this argument about knowledge to the consideration of values, maintaining that absolute values (such as pure beauty or pure benevolence) were the expression of highest physiological development of our "organ of feeling" (Organ des Fühlens; 115-125). This anti-relativistic tendency of Rothacker's early concepts of knowledge and values is significant in light of his later discussions of relativism, taken up below.

At this point the political undercurrent of Rothacker's biologistic determinism should be obvious: He divided humanity into particular groups and ranked them in terms of an assumed "natural" hierarchy of capacities. This hierarchy naturalized cultural and social differences. Rothacker's theory was intended to justify existing power relations within and between social groups as natural. We can therefore justifiably say that the early Rothacker was a biological racist and a social Darwinist: He assumed that human communities developed analogues to organic life.

From a methodological point of view, the early Rothacker conducted a study that corresponds to the so-called "weak program” of Völkerpsychologie (Kusch 2019): He searched for biological causal explanations of cultural development, and his biological determinism prioritized the community over the individual. He also blurred the lines between descriptive explanations and normative interests. He embraced a hierarchical understanding of cultural development and was neither an epistemic relativist nor a value relativist. Finally, Rothacker showed a hostility towards sociology that was typical of the völkerpsychological approaches around 1900 (see Klautke 2013, 75). 


\section{The Middle Rothacker (1919-1928): "Historicist'Lebensphilosophie"}

Rothacker's philosophical orientation changed dramatically after WWI. Following Dilthey, he developed a philosophy of the human sciences in the spirit of the Historical School. Rothacker published a new Einleitung in die Geisteswissenschaften (Introduction to the Human Sciences) in 1920 and aimed to complete Dilthey's project of a philosophical foundation of the human sciences in his Logik und Systematik der Geisteswissenschaften (Logic and System of the Human Sciences; 1926). Rothacker now favored a hermeneutical approach to cultures that emphasized their particularity, historicity, and creativity. He praised the historicist concept of the Volksgeist for having captured the very character of cultural productivity. The historicists aimed to reveal the "life-concern" (Lebensbezug) of cultural phenomena by relating them to the concrete fate of historical agents (Rothacker 1926, 129, 138, $157 \mathrm{f}$.). During this middle period, Rothacker characterized the "hidden philosophy of the Historical School" (130) as "historicist "Lebensphilosophie"" (147). He retained his earlier dismissal of sociology, but now rejected all causal explanations of culture, including all kinds of naturalism (see, e.g., 143).

The mid-career Rothacker was no aberration, and fits within one of the main lines of development in German philosophy after WWI. This historical context makes the major shift of his philosophical views plausible, but does not explain it sufficiently. ${ }^{\text {iv }}$ German philosophers' war-time propaganda associated naturalism with the "Western" culture of Germany's French and British enemies. With Germany's defeat, critical theories of modernity were reinforced, and the scientific worldview, with its "shallow" causal explanations, became identified with the alleged intellectual crisis of the modern mind. Weimar culture thus was partly characterized by an anti-scientific mentality, in which Lebensphilosophie flourished as a "German" alternative to "Western" thought (see Kusch 1995, 224-252). ${ }^{\mathrm{v}}$ In his middle period, Rothacker emphasized the distinctively "German tradition" of the Historical School 
(Rothacker 1920, 277, 1926, 114, 168). In the intellectual context of Weimar,

Völkerpsychologie declined as an academic discipline searching for the universal laws of human development. Thus for example, Felix Krüger, Wundt's student and successor, rejected the term Völkerpsychologie and accused his teacher Wundt of having come too close to the "positivism" of "Western" thought (Klautke 2013, 86-88). Krüger even turned to Dilthey's descriptive psychology as a methodological alternative to experimental psychology (Kusch 1995, 266-68).

In his mid-career, Rothacker extended Dilthey's theory of philosophical worldviews to the human sciences and culture in general. He argued that the methodological debates about scientific principles reflected fundamental "struggles of life" $(1926,112)$. The debates between naturalists, idealists, and historicists could thus be reduced to ideological differences between general worldviews. Like Dilthey, Rothacker distinguished between "naturalism," an "idealism of freedom," and "objective idealism" (36-67). Rothacker understood these worldviews as in conflict with each other, which was not Dilthey's understanding: Dilthey regarded the metaphysical worldviews as different perspectives rooted in distinct general attitudes to life, namely cognition, feeling, and volition (Dilthey 1962, 65 f.). To Dilthey, these represented different aspects of the world and, hence, were not necessarily in conflict with each other. Rothacker, on the other hand, saw these metaphysical worldviews as rooted in comprehensive decisions about life. They expressed practical demands and ethical postulates that could not be reconciled (137-139). For Rothacker, all knowledge was thus guided by normative interests (151).

During this middle period, Rothacker was aware that his theory of worldviews would invite the charge of relativism. In his discussion of the relativistic consequences of his view, he distinguished between a "positive" and a "negative" relativism. Rothacker suggested that negative relativism was a form of skepticism; it had to be rejected because of its "corrosive" (zersetzend) effects (148). Yet, Rothacker embraced "positive relativism" in both 
epistemology (a) and value theory (b). He employed a similar argument in both cases to show that his relativism had no unacceptable consequences.

\section{(a) Epistemology}

For Rothacker, the pursuit of knowledge was always motivated by practical interests anchored in worldviews, making truth interest-dependent. He held that the constitutive role of interests in knowing added a new dimension to epistemology, one which he tried to bring out by distinguishing between relevant and irrelevant truths. Still, Rothacker emphasized that this pragmatic criterion of knowledge did not affect the theoretical or empirical correctness of a claim: A certain claim may be irrelevant to us, but nevertheless true (144 f.).

\section{(b) Value Theory}

Rothacker admitted that his theory of worldviews followed historicism in acknowledging the plurality of values. The choice between different values was also guided by the particular interests of agents deciding between different possibilities of life. Rothacker maintained that adopting this perspective of life added a new dimension to the philosophical question about values: Values could be assessed by their "vitality" (Erlebtheit) and "genuineness" (Echtheit). This additional criteria made it possible to decide which values were "truly valuable" (wahrhaft wertvoll) in a specific context (147 f.).

Rothacker's theory of worldviews was rooted in a specific concept of life, one that emphasizes life's historical and practical character. This he understood in an almost existential way, arguing that life put its agents in a concrete situation (Situation) that called for a definite action. This necessity to act called for decisions that ground human creativity. Rothacker assumed that creative agents could be either collective (the Volksgeist) or individual $(155-157)$. This "scheme of productive life" $(159,171)$ granted creative agents more freedom than Rothacker's early biologistic concept of culture had. Now, in this middle 
period of his work, Rothacker began to explicitly relativize the influence of hereditary factors in cultural production, with an emphasis on their ethical aspects. The sources of productivity, "character" and "substance," were not simply given, but had to be acquired through "selfcreation" and "self-affirmation" (159 f.). Yet he explicitly set his approach apart from an individualistic understanding of cultural history, rejecting the idea that cultural development rested on the creativity of individual genius only. Rothacker regarded this extreme individualism as rooted in strands of romanticism that he rejected (29). He emphasized that each individual participates in various "historical" and "spatial" communities. These communities are bearers of "historical substances" that shaped spiritual life. The "historical substances" could be assessed primarily by reference to their "fecundity" (Fruchtbarkeit). An individual could develop a productive attitude only within "historical substances", and always remained trapped within them (164 f., 170 f.). Therefore, while Rothacker in this middle period placed collective entities above individuals, he nevertheless rejected a causal interpretation of this relationship, maintaining that individual cultural creativity was circumscribed by the communal context.

The last chapter of Rothacker's Systematics and Logic of the Human Sciences (Systematik und Logik der Geisteswissenschaften) shows the political aspect of his engagement with the Historical School (168-71; see also 117-119). Rothacker praises this movement's emphasis on the particularity of national cultures as a necessary response to the leveling character of the Enlightenment's universal aspirations. In embracing the value of concrete substances, and especially Völker, historicism revealed the productivity of cultural particularism. Rothacker closed his systematic treatise with an explicitly political statement, claiming that the discoveries of the Historical School entitled philosophers to patriotism (171). In a nutshell, the middle Rothacker emphasized the counter-Enlightenment character of historicism, and personally identified with its conservative and nationalist tendencies. He characterized the historicists as proponents of the "will of a great Volk" in search of its 
national culture (148). Rothacker saw the deepening of historical consciousness as an opportunity to return to the national values of the "German tradition" (Rothacker 1920, 22628; see also Plas 2011, 474-476; Stöwer 2012a, 73-75).

This political orientation is confirmed by Rothacker's political attitude during the Weimar Republic. Stöwer (2012a, 77-81) describes Rothacker's conduct in the highly politicized atmosphere of Heidelberg, where he worked from 1919 to 1929. Rothacker explicitly avoided the circle around Marianne and Alfred Weber where many of his liberal and socialist colleagues met regularly. He preferred the company of Friedrich Gundolf ,who introduced him to the circle gathered around the poet Stefan George (George-Kreis). Rothacker shared the elitist and anti-democratic conservativism of many of George's followers. In his autobiography he explained his rejection of the Weimar Republic with his strong belief that Germany had been humiliated after World War I (Rothacker 1963, 67). His anti-democratic attitude was thus closely connected with his nationalism. It is thus not surprising that he aligned himself with the politically conservative Deutsche Volkspartei (German People's Party), which combined a skeptical attitude towards the Weimar Republic with a nationalist, elitist, and anti-socialist agenda, and of which he was a member from 1919 to 1928.

\section{The Later Rothacker (1929-1945): Cultural Anthropology}

Rothacker changed the bedrock of his philosophy for a second time when, around 1930, he followed the anthropological turn in German philosophy (Scheler, Plessner) and took a more serious interest in recent developments in biology (Uexküll) and Lebensphilosopie (Spengler, Klages). His later theory of culture was first developed in his treatise Geschichtsphilosophie (Philosophy of History) in 1934. In 1942, Rothacker published a second treatise on the same topic that continued his earlier work, coining the term "cultural anthropology" (Kulturanthropologie) for his approach. 
The fundamental revision of his philosophical thought was accompanied by a political radicalization: Rothacker turned to National Socialism even before Hitler's seizure of power. He signed a petition calling for Hitler's election in July 1932, and became a member of the NS Lehrerbund (the Nazi organization for teachers) in November 1932 and of the NSDAP in May 1933. ${ }^{\mathrm{vi}}$

In the following section on Rothacker's later philosophy, I first sketch his methodological and political orientation (a), and then turn to the key motifs of his concept of culture (b).

\section{a) Methodological Demarcations and Political Affiliations}

Between his two treatises on the concept of culture, Rothacker (1938) published a psychological treatise on personality that positioned his cultural anthropology in relation to Völkerpsychologie, now taking a critical position. The chapter on Völkerpsychologie followed the contours of general psychology. Rothacker emphasizes that human behavior is always shaped by historically contingent cultural norms. He believed that the significance of culture and history confronts psychology with two problems. First, the focus on the individual mind is not sufficient to explain human characteristics. Second, the cultural level of human behavior cannot be adequately examined by experimental methods, which exposes the limited scope of causal explanation in psychology. Rothacker concluded that cultural studies had to complement Völkerpsychologie. He introduced his cultural anthropology as the theoretical and institutional framework that could bring together cultural and psychological studies to foster a comprehensive understanding of humanity (Rothacker 1938, 71-78).

Rothacker's proposal for examining the cultural aspect of human behavior was hermeneutic in a broad sense: He emphasized that humans behaved in meaningful ways and that human phenomena should by examined by a descriptive analysis of the "plain experience of life" (schlichte Lebenserfahrung; 1934, 42). This hermeneutic approach demanded a 
comparative study of the historical forms of human life. Rothacker's method was still visibly inspired by Dilthey.

In this later period of his work, Rothacker rejected naturalism and often criticized causal explanations of human behavior. He dismissed biology, psychology, Völkerpsychologie, sociology, and existing forms of philosophical anthropology because of their naturalistic concept of humanity (Rothacker 1934, 19, f., 22, 41-43, 1942/1948, 61 f.). In contrast to the alleged one-sidedness of naturalism, Rothacker promised a "synthetic science of the human being" (synthetische Wissenschaft vom Menschen) that considered all aspects of human life: nature and spirit, origin and tradition, lawfulness and spontaneity, knowledge and deed (1942/1948, 61 f., 192, 197 f., 1934, 37, 144 f.).

Rothacker criticized contemporary sociology from another angle as well. He now claimed that human communities had to be transformed into a unified Volk before they were capable of developing an advanced culture. The Volkswerdung (becoming a Volk) of a group was a political act and as such contingent (1942/1948, 93 f.). Rothacker wanted sociology to acknowledge the völkisch form of human life, calling for a National Sociology that would replace class with Volk (Rothacker 1933). With this nationalist focus, sociology could support the new supreme discipline of the humanities, namely Rothacker's "synthetic science of the human." The völkisch renewal of sociology was a key issue in Rothacker's public engagement in the 1930s: In newspaper articles and speeches he outlined how the human sciences could foster the rise of the German nation, envisioning Nazi Germany as a "self-conscious cultural state" (selbstbewusster Kulturstaat; Rothacker 1932a). ${ }^{\text {vii }}$

The later Rothacker was not shy about the political character of his philosophy. He emphasized that one of his key thoughts - the significance of proving oneself in a certain situation (Bewährung in einer bestimmten Lage; 1942, 64) — was directly drawn from political experience. This concept was important in his philosophical reading of National Socialism (NS). Rothacker explicitly associated his cultural anthropology with the rise of NS. In the first 
section of his Geschichtsphilosophie (1934), he claimed that his philosophical approach depended on the current historical developments, inasmuch as his philosophy revealed the anthropological foundation of the renewal of "folkish consciousness" (volkstümliche Bewußtsein; 1934, 3). In the last chapter, entitled "In the Third Reich", Rothacker argued that his philosophy belonged to this new political order, which he presented as a political revolution realizing a new image of humanity. He considered NS to be a kind of reality test for his cultural anthropology, advancing a reading of Nazi policies from the perspective of his theory of culture and justifying them philosophically. He argued that NS was the political response of a specific community to an ambivalent situation: On the one hand, an abundance of inner forces called for the shaping of the German Volk, yet on the other hand "hateful enemies and enviers" (149) threatened this project. NS understood the task that arose from the tension between the inner and outer situation: Germany had to assert itself against hostile foreign powers. Rothacker claimed that his concept of "proving oneself in a certain situation" explained the political primacy of foreign affairs typical of Nazi politics. His cultural anthropology aimed to show that the "protection of our sovereignty and borders" (149) had to be accompanied by the comprehensive mobilization of inner forces to establish a particular attitude (Haltung), which he characterized as being German. Rothacker held that being united in a stable attitude gave more strength to a community than any "constitutional crutches" (Verfassungskrücken) ever could (150). This conviction matched the self-understanding of NS as an ideological movement that shaped all aspects of life, so it is not surprising that Rothacker confidently concluded that the rise of this movement confirmed his philosophy of history. He also emphasized the philosophical significance of the guiding principles of the movement's ideology, arguing that the Nazi concepts of "state," "Volk," "race," and "Führer" contributed to the self-understanding of humanity and corresponded to his cultural anthropology (145-148). 
Rothacker belonged among the many philosophers who welcomed National Socialism because of its promise to realize a new concept of the human (for a detailed account of the philosophical collaboration with NS see Sluga 1993; Wolters 1999; Sieg 2013). Philosophers such as Alfred Baeumler (1887-1968), Ernst Krieck (1882-1947), and Arnold Gehlen (19041976) defined their own task as establishing a new conception of humanity in the realm of theory, corresponding to the new political reality. Anthropology thus became an important way to understand National Socialism philosophically. In this context, Rothacker's focus on culture made his approach stand out.

\section{b) The Key Motifs of Rothacker's Cultural Anthropology}

Völkisch particularism was at the core of Rothacker's cultural anthropology. Rothacker construed history as the struggle of particular communities for the realization of their life and their world $(1934,38)$. Human history was shaped by the cultural existence of those Völker who constituted the peak of human excellence. Only these communities possessed historical significance; all other "human societies" were justifiably forgotten (see, e.g., 1934, 53). Philosophy thus had to provide insight into the "life laws of Völker" (Lebensgesetze der Völker; 1934, 5), which Rothacker attempted to do by clarifying how human societies developed into advanced cultures (Hochkulturen).

The later Rothacker defined Völker as the "bearers and creators" of all "moral, cultural, and spiritual life" (38). Völker were characterized both biologically and culturally: Rothacker held that Völker rested on biological groups (families, clans, tribes, and the like) which ensured continuity over time, while a shared a way of life provided common spiritual forms. A Volk established a specific attitude in its struggle with the natural and social environment. The principles of these struggles were: "digest and assimilate" and "eat and be eaten" (38). Rothacker's basic concept of communities was thus social Darwinist, with his 
explicit assumption that the life of human communities was analogous to the life of organisms or a species (38).

Rothacker developed an existentialist understanding of the collective life of humanity. He regarded communities as thrown into a certain "situation" (Lage) which called for an adequate "response" (Antwort): A community had to prove itself. Only a "good idea" (guter Einfall) triggered a course of action that lead to a successful response to the challenges of the world. The lived experience of collective agents was the horizon of both the idea and the response, both of which were entirely relative to the communal lived experience. Rothacker illustrated this fundamental structure of human life by describing the situation of a sail boat in a heavy sea. Strong winds and heavy swells called for certain responses. The sailors had to master the challenge by their coordinated activity. Rothacker used this same example to illustrate his thought that over time and with experience sailors formed habits that helped them to answer their maritime challenges effectively (44 f.). In a similar way, he thought that stable attitudes (Haltungen) formed the core of a people's specific "styles of life" (Lebenstile) and were thus the foundation of human cultures. Consequently, Rothacker understood the sailors' attitudes as the core of a maritime style of life. When this style of life shaped and unified all vital expressions of a sailing community, a veritable "sailors' culture" emerged (46).

Rothacker held that cultures were rooted in a shared way of life. Cultures emerge when the specific attitude of a community finally is molded into a "characteristic form" (durchgeprägte Form), which shapes all areas of life. Rothacker defined the "characteristic form" of Kulturvölker (cultural people) as particular, collective, public, homogeneous, comprehensive, and productive. He claimed, for example, that there was a unique Roman style that characterized Roman heads, Roman architecture, each sentence of Roman historiography, each trait of Roman morality, and so on. This Roman identity was a basic disposition transmitted and modified from generation to generation and constituted the 
essence of being Roman, in which all members of the Roman community participated (73-79, 1942/1948, 68 f.). For Rothacker, "reduction" was a historical method, inasmuch as he assumed that the manifold products of a culture could be reduced to a specific "mental form" (seelische Form). The general tendency of the Volksgeist was expressed in the particular world of shaped forms. Here the cultural form should be understood as an expression of the spiritual life of a Volk (1934, 120-132, 1942/1948, 147-150).

Rothacker considered cultures to be separate and internally uniform entities, even though the unity of a style of life was never simply given. He viewed culture as the permanent task of shaping self and world. He emphasized that only permanent pressure and forceful coercion could facilitate the highest cultural achievements. A cultural style had to prove its productivity, preserve its unity, and succeed in the struggle with its environment. Social differences within a community could give rise to different versions of its specific style. For instance, Rothacker drew an analogy between how the style of the "leading classes" (Führungsschichten) and that of the "root classes" (Wurzelschichten) differ, and the difference between the spiritual and physiological expression of a culture. It was, however, essential that the unity of the cultural style be preserved, since the emergence of different class styles could endanger the unity of a culture (1942/1948, 178 ff.). Here Rothacker's social conservatism surfaced again: The imperative to stay in line suppresses the emancipatory struggle of social groups underrepresented in the cultural style of a given community.

In his 1934 treatise, Rothacker used the concept of "substance" to signify the persisting character of collective attitudes and cultural styles (70, 113-117; see also 1942/1948, 67). Race was defined as one aspect of the "complex substance" of a culture. The later Rothacker understood race as a natural potential that had to be realized through "breeding" and "shaping." This led to an acknowledged methodological problem: Since races were only known in their historical form of Völker, only their phenotypes could be identified 
(1934, 136 f.). From this Rothacker concluded the "issue of race" (Rassenfrage) did not necessarily require a biologistic approach that identified natural dispositions and used them as causal explanations (1934, 41, 136 f., 1942/1948, 193-195). He praised the work of Ludwig Ferdinand Clauß, who studied alleged racial types using a hermeneutic method $(1934,41$; 1942/1948, 78). Clauß believed that the physiological and mental expressions of communities revealed the soul of their race (Rassenseele), claiming that the character of a race could only be understood by witnessing (Mitleben) its special way of life (Clauß 1926/1933). ${ }^{\text {vii }}$ This understanding of race was compatible with anti-naturalism.

The later Rothacker rejected the social determinism that he associated with sociology in particular (Rothacker 1934, 117-120, 1933, 1932b), yet he did not give up the belief in the priority of the community. In comparison to his middle period, Rothacker developed a more complex understanding of the relationship between the individual and its collective affiliations. In his later work, Rothacker thought the life of each human being took place in a culture whose collective substance determined the character of all individual acts, thus shaping a person's identity $(1942 / 1948,192)$. Yet, this cultural disposition could also transform into a situation (Lage) in which the individual had scope for decisions, and individual action could modify culture. Rothacker also mentioned the possibility of completely abandoning of one's cultural dispositions, though he warned against the use of absolute freedom and emphasized its futility. Individuals were creative only within their native culture. Rothacker emphasized that a culturally-shaped individual was "substantially enriched" but not "causally tied" (1934, 115 f.). He embraced the dominance of collective dispositions, but rejected causal interpretations of how the individual interacts with these (see also 1932b, 13-15).

In his later work, Rothacker assumed that his particularistic understanding of cultures would invite the charge of relativism. He thus examines the problem of relativism again, but restricts his discussion to epistemology $(1934,86,1942 / 1948,177)$. He still believes that 
practical interests played a constitutive role for knowing, though he also emphasizes the significance of desires and emotions for epistemic pursuits. The later Rothacker draws connections between his characterization of the human epistemic situation and the pragmatic criterion of truth encountered in his middle work. He distinguishes between relevant and irrelevant truths, claiming that this pragmatic dimension does not affect the correctness of epistemic claims $(1934,94-99,1942 / 1948,162-166)$. In contrast to his middle phase, the later Rothacker rejects the label of "relativism" for his view, emphasizing its realistic core. Divergent perspectives select between different aspects of the same reality, which he illustrates by way of a simple example: The same place can be spontaneously interpreted by a farmer as a wood, a forester as a forest, a hunter as a hunting ground, and a fugitive as a hiding place (1934, 85 f., 1942/1948, 161, 170 f.). Rothacker argues that the interpretations corresponding to each set of interests, desires, and emotions were objective knowledge about the world. He also claims that diverging worldviews do not contradict each other on an epistemic level (173). However, the different styles of life remain in practical conflict about which world and life was "truly worth" (wahrhaft würdig) living $(1934,99)$. Communities had to prove the value of their attitudes in a struggle with other communities, with the winner being credited with a better answer to the challenges of life and, hence, a superior style of life. The later Rothacker did not consider whether this position amounted to value relativism, since he restricted the problem of relativism to epistemology.

In the 1930s and 40s, Rothacker developed a new theory of culture that included key motifs of his earlier works: He kept the hermeneutical orientation of his Diltheyan period and rejected naturalistic approaches to culture, while advancing revised versions of the existentialist concept of life and the cultural particularism that characterized his middle work. Rothacker's later philosophy thus is often read as an anthropological foundation for his theory of worldviews (Stöwer 2012a, 2012b; Tremmel 2012, 2009; Plas 2011; Fischer 2008). There are, however, also connections to key convictions of his early work, despite the explicit 
critique of the biologistic concept of culture that the early work embraced. The later

Rothacker was still a social Darwinist who worked with analogies between human and natural life - although he developed a different concept of life. He regarded cultures as expressions of the spiritual life of human communities, believed in the priority of community, and retained the old hostility towards sociology. But he distinguished his culturalism from all kinds of causal determinism and claimed that it left room for individual freedom. Rothacker's völkisch anthropology was guided by normative interests and was intended to justify both cultural and social hierarchies. It thus should not surprise us that Rothacker granted völkerpsychological examination a place in his "synthetic science of the human", nor that he should present his cultural anthropology as the long-overdue comprehensive answer to issues first raised by Völkerpsychologie. The later Rothacker's discussion of relativism is a special case: While he kept central thoughts from his middle work, he restricted his discussion to epistemology. $\mathrm{He}$ emphasized the realistic core of his perspectivism in order to distinguish his view from relativism. Rothacker's later work was characterized by an anti-relativistic tendency.

\section{Conclusion}

The analysis above focuses on two aspects of Rothacker's philosophy of culture. First, the significance of Völkerpsychologie and Dilthey's Lebensphilosophie for the development of Rothacker's philosophical thought is emphasized. The paper begins by sketching Rothacker's völkerpsychological beginnings and analyzing his early biologist concept of culture. Then the analysis turns to Rothacker's Diltheyan philosophy of the human sciences, showing that, in the middle period of his work, Rothacker revised his understanding of human culture in line with ideas associated with historicism. He developed a theory of worldviews, embraced an existentialist concept of life, and deepened his particularism. The paper concludes by evaluating the second fundamental revision of Rothacker's philosophy, arguing that his cultural anthropology is best seen as a development of motifs of his earlier works. While the 
straightforward link between his middle and later work is acknowledged by most commentators, I also pointed to the more subtle connection to his early work on culture. The later Rothacker rejected naturalism, but retained certain convictions that were now justified by the culturalist framework of his völkisch anthropology.

Second, this paper emphasizes the political aspect of Rothacker's philosophy, showing that his different approaches to human culture shared a conservative tendency that corresponded to his political affiliation during the Weimar Republic and under NS. This political conservativism was deeply entrenched in Rothacker's theories of culture, which are presented here as different forms of völkisch thinking exhibiting a common pattern of assumptions about humanity—despite their important differences. Rothacker's philosophical approaches were always guided by normative interests. They carved the world up into unified entities whose members shared a particular identity. Rothacker emphasized the competition among these collective entities and ranked them according to their alleged achievements, assuming a deep distance between different forms of human life, and essentializing social differences by analyzing them in terms of natural or cultural characteristics. Finally, Rothacker always placed the community above the individual, thus attempting to justify nationalism philosophically. Since his philosophy was shaped by the reception of Völkerpsychologie and Lebensphilosophie, the political orientation of his thought demonstrates problematic aspects of their legacy.

\section{References}

Böhnigk, Volker. 2002. Kulturanthropologie als Rassenlehre: nationalsozialistische Kulturphilosophie aus der Sicht des Philosophen Erich Rothacker. Würzburg: Königshausen und Neumann. 
Chickering, Roger. 1993. Karl Lamprecht: a German Academic Life (1856-1915). Atlantic Highlands/NJ: Humanities Press.

Clauß, Ludwig F. 1926/1933. Rasse und Seele. 3rd ed. München: Lehmann.

Dilthey, Wilhelm. 1962. The Essence of Philosophy. Trans. Stephen Emery and William Emery. Chapel Hill: The University of Carolina Press.

Fischer, Joachim. 2008, Philosophische Anthropologie. Eine Denkrichtung des 20. Jahrhunderts, Freiburg: Alber.

Habermas, Jürgen. 1958/1973. "Philosophische Anthropologie.” In Kultur und Kritik: verstreute Aufsätze, 89-111. Repr. Frankfurt/M.: Suhrkamp.

Klautke, Egbert. 2013. The Mind of the Nation: Völkerpsychologie in Germany, 1851-1955. New York and Oxford: Berghahn Books.

Koonz, Claudia. 2003. The Nazi Conscience. Cambridge/Mass.: Harvard University Press. Koslowski, Peter. 1997. “A Philosophy of the Historical School: Erich Rothacker's Theory of the Geisteswissenschaften.” In Methodology of the Social Sciences, Ethics, and Economics in the Newer Historical School, ed. Koslowski, 510-529. Berlin: Springer.

Kroll, Frank-Lothar. 1998. Utopie als Ideologie. Geschichtsdenken und politisches Handeln im Dritten Reich, Paderborn: Schöningh.

Kusch, Martin. 1995. Psychologism. London and New York: Routledge.

—. 2019. "From Völkerpsychologie to the Sociology of Knowledge." HOPOS, forthcoming.

Plas, Guillame. 2011. "Philosophische Anthropologie als Anti-Soziologie. Erich Rothackers früher Entwurf einer Kulturanthropologie im theoretischen Feld der Weimarer Republik." In Konkurrenz der Paradigmata. Zum Entstehungskontext der philosophischen Anthropologie, ed. Plas and Gérad Raulet, 471-494. Nordhausen: Bautz. 
. 2013. "Ernst Cassirers und Erich Rothackers Kulturmorphologien. Von der ideologischen Offenheit des Historismus." In Philosophische Anthropologie und Politik, ed. Plas, Raulet, and Manfred Gangl, 199-217. Nordhausen: Bautz.

Raphael, Lutz. 1990. „Historikerkontroversen im Spannungsfeld zwischen Berufhabitus, Fächerkonkurrenz und sozialen Deutungsmustern." Historische Zeitschrift 252:325-363.

Rothacker, Erich. 1909. “Über die Möglichkeit der Völkerpsychologie.” Zeitschrift für angewandte Psychologie und Charakterkunde 2:382-392.

1912. Über die Möglichkeit und den Ertrag einer genetischen Geschichtsschreibung im Sinne Karl Lamprechts. Leipzig: Voigtländer.

— 1920. Einleitung in die Geisteswissenschaft. Tübingen: Mohr.

—. 1926. Logik und Systematik der Geisteswissenschaften. München and Berlin:

Oldenbourg.

. 1932a. "Neue Wege des Hochschulwesens.” In Hochschulfragen. Eine Sammlung von Vorträgen, ed. Westdeutscher Rundfunk, 48-54. Köln: Bachem.

—. 1932b. "Überbau und Unterbau, Theorie und Praxis." Schmollers Jahrbuch 56:1-16

—. 1933. "Nationale Soziologie.” Westdeutsche Akademische Rundschau 3:1.

—. 1934. Geschichtsphilosophie. München and Berlin: Oldenbourg.

—. 1938. Die Schichten der Persönlichkeit. Leipzig: Barth.

—.1942/1948. Probleme der Kulturanthropologie. Repr. Bonn: Bouvier.

—. 1963. Heitere Erinnerungen. Frankfurt/M.: Athenäum.

Schorn-Schütte, Luise. 1984. Karl Lamprecht: Kulturgeschichtsschreibung zwischen Wissenschaft und Politik. Göttingen: V\&R.

Sieg, Ulrich. 2013. Geist und Gewalt. Deutsche Philosophen zwischen Kaiserreich und Nationalsozialismus. München: Hanser.

Simmel, Georg. 1908. “Über das Wesen der Sozialpsychologie.” Archiv für Sozialwissenschaft und Sozialpolitik 26:285-291. 
Sluga, Hans. 1993. Heidegger's Crisis: Philosophy and Politics in Nazi Germany.

Cambridge/Mass.: Harvard University Press.

Stöwer, Ralph. 2012a. Erich Rothacker: Sein Leben und seine Wissenschaft vom Menschen.

Göttingen: V\&R University Press.

_.2012b. "Rothackers Kulturphilosophie in biographisch-zeitgeschichtlicher

Perspektive." FIB 1:49-58.

Tremmel, Frank. 2009. "Menschheitswissenschaft" als Erfahrung des Ortes. Erich Rothacker und die deutsche Kulturanthropologie. München: Utz.

—. 2012. "Leben in Begriffen. Erich Rothackers Kulturanthropologie als historische Semantik der "existentiellen Reduktion." FIB 1:59-64.

Weber, Thomas. 1989. “Arbeit am Imaginären des Deutschen. Erich Rothackers Ideen für eine NS-Kulturpolitik.” In Deutsche Philosophen 1933, ed. Wolfgang F. Haug, 23-39. Reinbek/Hamburg: Argument.

Wolters, Gereon. 1999. “Der 'Führer' und seine Denker. Zur Philosophie des 'Dritten Reichs.” Deutsche Zeitschrift für Philosophie 47:223-251.

Wundt, Wilhelm. 1886/1911. “Ziele und Wege der Völkerpsychologie.” In Probleme der Völkerpsychologie, 1-35. Leipzig: Wiegandt.

${ }^{\mathrm{i}}$ Since there is no established English translation of the term Völkerpsychologie, I use the German term in my paper.

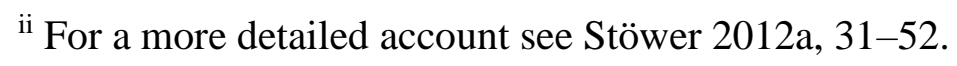

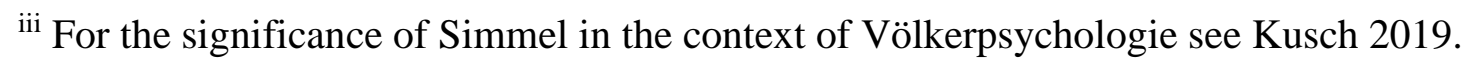

${ }^{\text {iv }}$ Examining the question why Rothacker changed his philosophical views after WWI would require a detailed analysis of Rothacker's work and life during the war that extends the scope of this paper (see Stöwer 2012a, 52-56). 
${ }^{\mathrm{v}}$ For the nationalist tendencies of German philosophy during and after WWI see Sieg 2013.

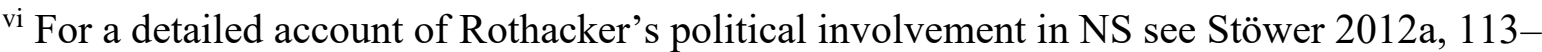
154.

${ }^{\text {vii }}$ For the political aspect of Rothacker's critique of sociology see Plas 2013.

viii For the significance of non-biologistic concepts of race for Nazi ideology see, e.g., Kroll 1998; Koonz 2003, 190-220. 